\title{
Mature landfill leachate treatment by denitrification and ozonation
}

\author{
Susana Cortez, Pilar Teixeira, Rosário Oliveira*, Manuel Mota \\ IBB - Institute for Biotechnology and Bioengineering, Centre of Biological Engineering, University of Minho, Campus de Gualtar, 4710-057 Braga, Portugal
}

\section{A R T I C L E I N F O}

\section{Article history:}

Received 26 May 2010

Received in revised form 20 July 2010

Accepted 28 July 2010

\section{Keywords:}

Anoxic rotating biological contactor

Mature landfill leachate

Nitrate removal

Ozonation

Phosphorus

\begin{abstract}
A B S T R A C T
The removal of nitrate from a mature landfill leachate with high nitrate load in a lab-scale anoxic rotating biological contactor ( $\mathrm{RBC}$ ) was studied. Under a phosphorus-phosphate concentration of $10 \mathrm{mg}$ $\mathrm{P}_{-} \mathrm{PO}_{4}{ }^{3-} \mathrm{L}^{-1}$ and nitrogen-nitrate concentrations above $530 \mathrm{mg} \mathrm{N}-\mathrm{NO}_{3}{ }^{-} \mathrm{L}^{-1}$ the reactor achieved nitrogennitrate removal efficiencies close to $100 \%$, without nitrite or nitrous oxide accumulation. Although the reactor presented a very good denitrification performance, the effluent carbon concentration was still above the legal discharge value. In order to increase the biodegradability of the leachate recalcitrant carbon load, a pre-ozonation was further investigated. The pre-ozonation led to a total organic carbon (TOC) removal of $28 \%$. The sequence of treatments, leachate ozonation followed by RBC denitrification did not affect the denitrification efficiency. In fact, it was possible to attain a denitrification rate of $123 \mathrm{mg}$ $\mathrm{N}-\mathrm{NO}_{3}{ }^{-} \mathrm{L}^{-1} \mathrm{~h}^{-1}$. The moderate decrease in the carbon load of the final effluent indicated that some recalcitrant compounds were still present after ozonation. The anoxic RBC showed to be a promising technology for removing nitrate from landfill leachate.
\end{abstract}

(c) 2010 Elsevier Ltd. All rights reserved.

\section{Introduction}

Water and wastewater contamination by nitrate $\left(\mathrm{NO}_{3}{ }^{-}\right)$constitutes a major environmental concern worldwide. Biological nitrate reduction (denitrification) is the most widely used method to remove nitrate due to the high specificity of denitrifying bacteria, low cost and high denitrification efficiency [1]. In this process, under low oxygen levels, microorganisms first reduce nitrate to nitrite $\left(\mathrm{NO}_{2}^{-}\right)$and then produce nitric oxide (NO), nitrous oxide $\left(\mathrm{N}_{2} \mathrm{O}\right)$, and, finally, nitrogen gas $\left(\mathrm{N}_{2}\right)$. The production and accumulation of nitrite and other intermediary products are undesirable, since they are toxic, and are often referred to as incomplete denitrification. To ensure complete denitrification, since most denitrifiers are heterotrophs, sufficient carbon must be available. Denitrification efficiency is strongly susceptible to type of carbon source, concentration of carbon source, the carbon to nitrogen molar ratio $(\mathrm{C} / \mathrm{N})$ and the biomass activity. Phosphorus has also an important effect on denitrification efficiency [2,3].

Anoxic rotating biological contactors (RBCs) started to be used for denitrification of groundwater and synthetic wastewaters in the last decade $[2,4,5]$. An anoxic RBC unit typically consists of a series of closely spaced discs that are mounted on a common horizontal shaft and are partially or completely submerged in the wastewater to be treated and inserted in a tightly closed case to avoid air entrance. Similarly to an open RBC, the pollutants contained

\footnotetext{
* Corresponding author. Tel.: +351253604 409; fax: +351253678986.

E-mail address: roliveira@deb.uminho.pt (R. Oliveira).
}

in the wastewater are removed by the biofilm that is established on the entire surface area of the discs, which continually rotate. These reactors offer advantages such as compact design, simplicity of operation, low operating and maintenance costs, short hydraulic retention time (HRT), high biomass concentration, high specific surface area, resistance to toxic loads and relatively small accumulation of sloughed biofilm. RBCs have been applied for removal of ammonium and organic substances in the treatment of landfill leachate with high performance [6-8]. However, to the authors' knowledge, reports of nitrate removal from landfill leachate in anoxic RBCs are not found in the literature.

Landfill leachate has been generally known as a high-strength wastewater that is most difficult to deal with. Leachate generated from mature landfills is typically characterised by high ammonium $\left(\mathrm{NH}_{4}{ }^{+}\right)$content, low 5-day biochemical oxygen demand $\left(\mathrm{BOD}_{5}\right)$ to chemical oxygen demand (COD) ratio $\left(\mathrm{BOD}_{5} / \mathrm{COD}\right)$, or, in other words, low biodegradability and high fraction of refractory and large organic molecules [9]. In many cases, after treatment by a series of oxidation processes, mature landfill leachate still presents high concentrations of recalcitrant compounds and nitrate. When treating this type of leachate, biological methods are ineffective, while physico-chemical and advanced oxidation processes are expensive. By combining several treatment technologies, economical savings and process optimisations could be achieved due to the degradation of the refractory compounds into biodegradable organic matter and the use of these products as a carbon source for denitrification.

Ozone $\left(\mathrm{O}_{3}\right)$ has proved to be an effective oxidant for landfill leachate, due to its oxidation potential [10]. During ozonation, 

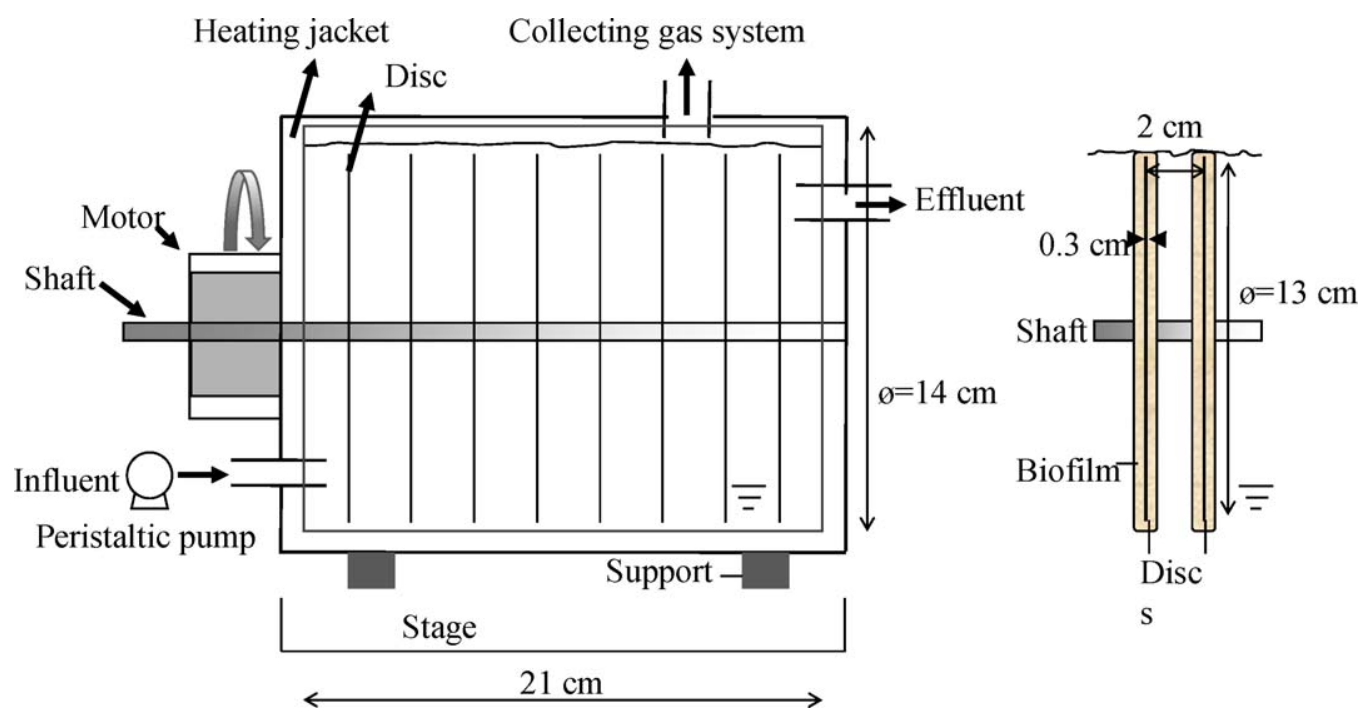

Fig. 1. Schematic diagram of the anoxic RBC.

organic compounds with long chains can be fragmented in lower chains, with an increase of their biodegradability, or degraded to carbon dioxide. Geenens et al. [11] used a combined treatment comprising ozonation before the biological process and verified that landfill leachate biodegradability increased after ozonation, resulting in a higher carbon removal by the biological process.

The purpose of this investigation was to evaluate the removal of nitrate from a mature landfill leachate with high nitrate load by denitrification in a lab-scale anoxic RBC, with previous ozonation to favour the biodegradability of the refractory organic load. Previously, the anoxic reactor was operated to optimise some parameters that affect denitrification efficiency such as phosphorus concentration and $\mathrm{C} / \mathrm{N}$ ratio. In order to clarify the results obtained with the combined treatments in continuous mode, batch experiments were also performed to evaluate the substrate removal rate.

\section{Materials and methods}

\subsection{Landfill leachate characteristics}

The landfill leachate was collected at the end of the treatment plant of a municipal landfill in the North of Portugal, in operation since 1998. This means that the leachate had already withstood a series of treatments including: stabilisation and anaerobic ponds, an anoxic tank, aerated ponds, decantation unit together with an oxidation tank and two chemical precipitators. The collected leachate was stored in closed containers at $4{ }^{\circ} \mathrm{C}$ until use. The characteristics of the undiluted leachate used in the experiments are summarised in Table 1.

The extremely low $\mathrm{BOD}_{5} / \mathrm{COD}$ ratio $(0.01)$ and the high content of nitrogenammonium $\left(\mathrm{N}-\mathrm{NH}_{4}^{+}\right)\left(714 \mathrm{mg} \mathrm{L}^{-1}\right)$ show that this leachate is mature and must be rich in refractory compounds. Another important feature of this already treated leachate is its high nitrogen-nitrate $\left(\mathrm{N}-\mathrm{NO}_{3}{ }^{-}\right)\left(1824 \mathrm{mg} \mathrm{L}^{-1}\right)$ content.

\subsection{Denitrifying reactor setup and operation}

The single-stage anoxic RBC consisted of 8 polymethylmethacrylate (PMMA) discs $(13 \mathrm{~cm}$ in diameter) mounted on a rotating shaft $(1.6 \mathrm{~cm}$ in diameter). The reactor working volume was $2.5 \mathrm{~L}$. The discs were completely immersed. The anoxic
Table 1

Landfill leachate average characteristics.

\begin{tabular}{ll}
\hline Parameter & Value \\
\hline $\mathrm{pH}$ & $3.5 \pm 0.1$ \\
Conductivity $\left(\mathrm{mS} \mathrm{cm}^{-1}\right)$ & $4.45 \pm 0.03$ \\
$\mathrm{COD}\left(\mathrm{mg} \mathrm{L}^{-1}\right)$ & $743 \pm 14$ \\
$\mathrm{BOD}\left(\mathrm{mg} \mathrm{L}^{-1}\right)$ & $10 \pm 1$ \\
$\mathrm{TOC}\left(\mathrm{mg} \mathrm{L}^{-1}\right)$ & $284 \pm 6$ \\
$\mathrm{~N}-\mathrm{NO}_{3}^{-}\left(\mathrm{mg} \mathrm{L}^{-1}\right)$ & $1824 \pm 103$ \\
$\mathrm{~N}-\mathrm{NO}_{2}^{-}\left(\mathrm{mg} \mathrm{L}^{-1}\right)$ & $<0.01$ \\
$\mathrm{~N}-\mathrm{NH}_{4}^{+}\left(\mathrm{mg} \mathrm{L}^{-1}\right)$ & $714 \pm 23$ \\
$\mathrm{P}-\mathrm{PO}_{4}^{3-}\left(\mathrm{mg} \mathrm{L}^{-1}\right)$ & $0.88 \pm 0.05$ \\
$\mathrm{VSS}\left(\mathrm{mg} \mathrm{L}^{-1}\right)$ & $79 \pm 3$ \\
\hline
\end{tabular}

RBC was covered and sealed and no special precaution was taken to maintain anoxic conditions. The rotational speed was $4 \mathrm{rpm}$ and the temperature was kept at $28^{\circ} \mathrm{C}$ by means of a heating jacket. Substrate was fed by a peristaltic pump at a constant hydraulic retention time (HRT) of $10 \mathrm{~h}$. The treated effluent was collected in a receiving tank. Flow through discs was parallel to the rotating shaft. A Ritter MilliGascounter was used to measure the rate of produced gas. A schematic description of the reactor is presented in Fig. 1.

The reactor was inoculated with sludge collected from an activated sludge tank at a municipal wastewater treatment plant and previously acclimatised. Sludge acclimatisation lasted approximately 1 month and occurred in anoxic conditions, at room temperature and $150 \mathrm{rpm}$, using two-fold diluted leachate supplemented with acetate $(\mathrm{C} / \mathrm{N}=2)$ and involved decanting and washing steps every 5 days.

To allow for biofilm development the reactor was operated in batch mode for 5 days. On day 6 , the anoxic RBC mixed liquor was removed, the reactor was re-filled and started to operate in a continuous mode. The hydraulic retention time, very high at the beginning, was gradually reduced. The time "zero" of operation was set 2 days after having the HRT stabilised at $10 \mathrm{~h}$, when samples started to be collected.

The study was conducted for a period of 21 days. During the assay, the landfill leachate load, $\mathrm{C} / \mathrm{N}$ ratio and phosphorus concentration were changed, while all other operation parameters were kept constant. Landfill leachate previously ozonated was fed to the reactor in the final period of the continuous experiment, as listed in Table 2.

Throughout the study, to overcome the low biodegradable carbon content of the leachate tested, sodium acetate was added as supplementary carbon source, since acetate is known to give the highest denitrification rates $[12,13]$. The amount of

Table 2

Operating conditions of the anoxic RBC

\begin{tabular}{|c|c|c|c|c|}
\hline Days of operation & Type of influent & $\mathrm{C} / \mathrm{N}$ & $\mathrm{N}-\mathrm{NO}_{3}{ }^{-}\left(\mathrm{mg} \mathrm{L}^{-1}\right)$ & $\mathrm{P}_{-} \mathrm{PO}_{4}{ }^{3-}\left(\mathrm{mg} \mathrm{L}^{-1}\right)$ \\
\hline $0-2.2$ & Two-fold diluted leachate & 2 & 912 & 0.44 \\
\hline $2.2-6.4$ & Four-fold diluted leachate & 2 & 456 & 0.21 \\
\hline $6.4-10.4$ & Four-fold diluted leachate & 2 & 456 & 10 \\
\hline $10.4-14.2$ & Four-fold diluted leachate & 1.4 & 456 & 10 \\
\hline $14.2-17.2$ & Two-fold diluted leachate & 1.4 & 912 & 10 \\
\hline $17.2-21.4$ & $\begin{array}{l}\text { Two-fold diluted and ozonated } \\
\text { leachate }\end{array}$ & 1.4 & 912 & 10 \\
\hline
\end{tabular}


sodium acetate needed to attain the desired $\mathrm{C} / \mathrm{N}$ was calculated taking into account the total organic carbon present in the landfill leachate. The required phosphorus concentration was achieved adding to the influent a calculated amount of $\mathrm{K}_{2} \mathrm{HPO}_{4}$. Due to the medium buffering capacity, no $\mathrm{pH}$ adjustment was performed.

\subsection{Ozonation}

Ozonation of the leachate was performed in an acrylic column $69.5 \mathrm{~cm}$ height and $8.2 \mathrm{~cm}$ internal diameter. Ozone was generated from pure oxygen using an ozone generator (Anseros Peripheral Com-AD-02). The inlet and outlet concentrations of ozone in the gas phase were measured at $254 \mathrm{~nm}$ using an ozone analyser (Anseros Ozomat GM-6000-OEM). The ozone and oxygen mixture was continuously introduced into the column through a ceramic diffuser placed at the bottom and $1 \mathrm{~L}$ of two-fold diluted leachate was treated in batch mode during $60 \mathrm{~min}$. The operation was conducted at adjusted $\mathrm{pH} 9$, at room temperature $\left(20 \pm 2^{\circ} \mathrm{C}\right)$ with a gas flow rate of $0.83 \mathrm{~L} \mathrm{~min}^{-1}$ and an inlet ozone concentration of about $112 \mathrm{mg} \mathrm{L}^{-1} \mathrm{NTP}$.

\subsection{Biofilm denitrifying activity}

At the end of the anoxic RBC operation, the biofilm formed on the discs was carefully removed and used in batch assays to evaluate the biofilm denitrifying activity. The assays were carried out in $160 \mathrm{~mL}$ vials using $90 \mathrm{~mL}$ of denitrifying medium. The denitrifying medium for a two-fold diluted leachate was different from the two-fold diluted and ozonated leachate, both with $\mathrm{C} / \mathrm{N}=1.4$ and $10 \mathrm{mg} \mathrm{P}-\mathrm{PO}_{4}{ }^{3-} \mathrm{L}^{-1}$. Each vial was inoculated with $5 \mathrm{~g}$ of biofilm (wet weight). Abiotic tests were also performed to determine abiotic losses of nitrogen and carbon, using similar conditions but without inoculum addition. Assays in the absence of carbon-acetate were also conducted. In any case, the vials were closed with butyl rubber stoppers and aluminium caps. To obtain anoxic conditions, the vials were flushed with helium. Finally, the vials were incubated at $28^{\circ} \mathrm{C}$ and $150 \mathrm{rpm}$. All the assays were performed in duplicate. Samples from each vial were collected at regular intervals and immediately analysed for several parameters.

\subsection{Chemical analyses}

$\mathrm{pH}$ values were measured with a $\mathrm{pH}$ meter Chemical oxygen demand (COD), nitrogen-nitrite $\left(\mathrm{N}-\mathrm{NO}_{2}{ }^{-}\right)$and nitrogen-ammonium $\left(\mathrm{N}-\mathrm{NH}_{4}{ }^{+}\right)$concentrations were determined according to Standard Methods [14]. COD was estimated using the closed reflux titrimetric method. $\mathrm{N}^{-\mathrm{NO}_{2}}{ }^{-}$and $\mathrm{N}-\mathrm{NH}_{4}{ }^{+}$concentrations were determined spectrophotometrically using $\mathrm{N}$-(1-naphthyl)-ethylene-diamine and Nessler's reagent, respectively. Nitrogen-nitrate $\left(\mathrm{N}-\mathrm{NO}_{3}{ }^{-}\right)$and carbon-acetate $\left(\mathrm{C}-\mathrm{CH}_{3} \mathrm{COO}^{-}\right.$) concentrations were measured by high-performance liquid chromatography (HPLC), using a Varian Metacarb column (type $67 \mathrm{H}, 9 \mu \mathrm{m}, 300 \mathrm{~mm}$ long, $6.5 \mathrm{~mm}$ internal diameter) and a mobile phase of $0.005 \mathrm{M}$ sulfuric acid $\left(\mathrm{H}_{2} \mathrm{SO}_{4}\right)$ at $0.7 \mathrm{~mL} \mathrm{~min}^{-1}$. Column temperature was set at $60^{\circ} \mathrm{C}$ and nitrate and acetate were detected by UV at $210 \mathrm{~nm}$. Periodically, gas samples were analysed by a gas chromatograph (GC) equipped with a thermal conductivity detector and a Porapak Q column ( $2 \mathrm{~mm}$ internal diameter, $80-100 \mu \mathrm{m}$ mesh, $1 \mathrm{~m}$ length) in series with a Molecular Sieve column ( 2 mm internal diameter, $5 \AA$, 80-100 $\mu$ m mesh, 2 m length). Helium was used as the carrier gas at a flow rate of $17 \mathrm{~mL} \mathrm{~min}^{-1}$. Temperatures of the injector port, columns and detector were 110,35 and $110^{\circ} \mathrm{C}$, respectively. Total organic carbon (TOC) analyses were performed using a Dohrmann DC-190 TOC Analyser.

\section{Results and discussion}

\subsection{Performance of the anoxic $R B C$}

\subsubsection{Nitrogenous compounds}

Fig. 2 shows the influent and effluent concentrations of nitrogenous compounds and the nitrate removal efficiency in the denitrifying reactor throughout the experiment. The denitrifying reactor was initially operated with a nitrate load of $1090 \mathrm{mg} \mathrm{N}$ $\mathrm{NO}_{3}{ }^{-} \mathrm{L}^{-1}$ and a carbon to nitrogen molar ratio $(\mathrm{C} / \mathrm{N})$ of 2 , using acetate as the additional carbon and energy source. This ratio is slightly higher than the theoretical value of 1.4 obtained considering the approach of McCarty et al. [15] when acetate is the carbon source. However, it is also necessary to consider that some carbon is used for the removal of oxygen from the system. Therefore, a conservative approach was made to insure complete denitrification. In this period, the reactor presented a very low performance in terms of nitrate removal. Considering that the high nitrate concentration could inhibit the microbial biofilm activity, the initial $\mathrm{N}-\mathrm{NO}_{3}{ }^{-}$concentration was reduced by increasing the influent dilution. However, this adjustment did not cause any change on nitrate
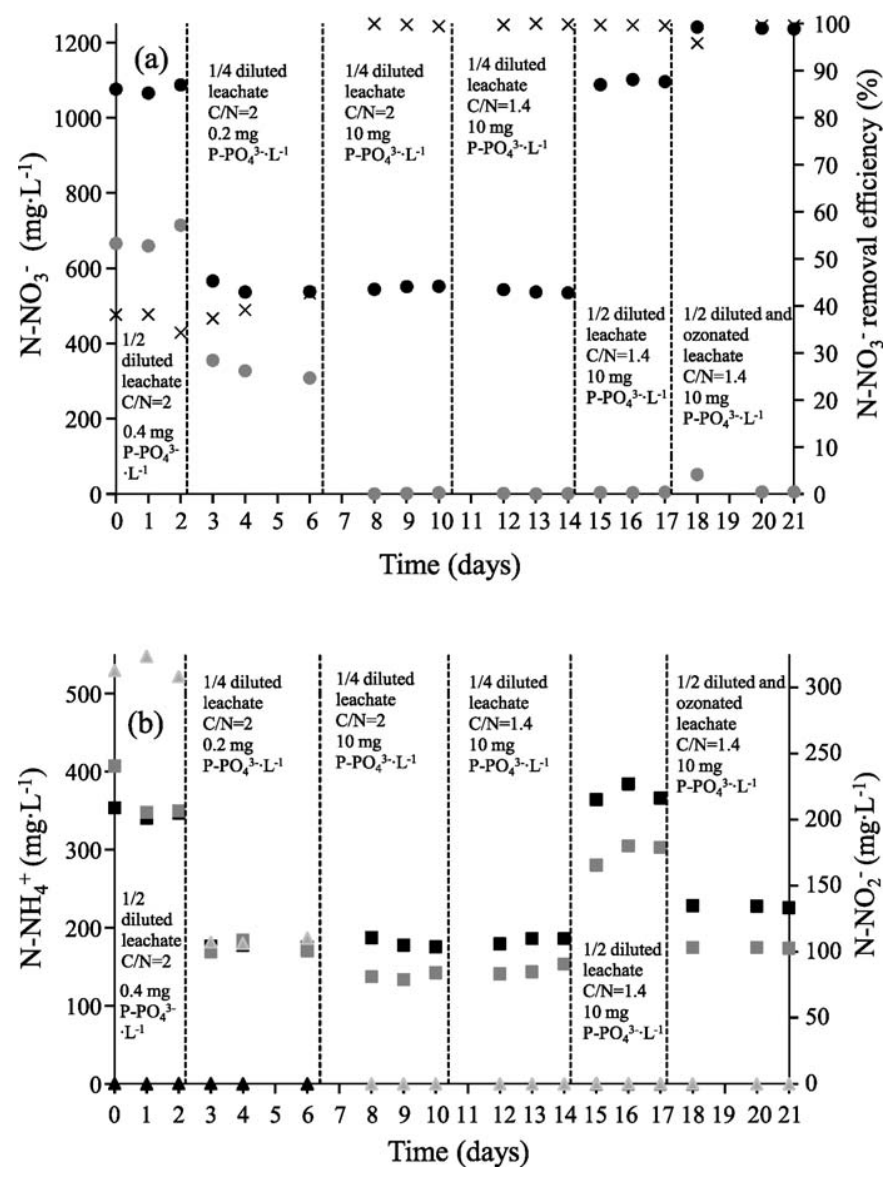

Fig. 2. Nitrogenous compounds profile in the denitrifying reactor throughout time (a) Influent (৩) and effluent $(\mathrm{O}) \mathrm{N}-\mathrm{NO}_{3}{ }^{-}$concentration and $\mathrm{N}-\mathrm{NO}_{3}{ }^{-}$removal efficiency $(\times)$. (b) Influent $(\boldsymbol{\square})$ and effluent $(\square) \mathrm{N}-\mathrm{NH}_{4}{ }^{+}$concentration, influent $(\boldsymbol{\Delta})$ and effluent $(\triangle) \mathrm{N}^{-\mathrm{NO}_{2}}{ }^{-}$concentration.

removal, indicating that the nitrate load was not the limiting factor

Considering that influent phosphorus concentration can significantly affect the denitrifying process [2,3], from day 6 onwards the $\mathrm{P}_{-} \mathrm{PO}_{4}{ }^{3-}$ influent concentration was changed to $10 \mathrm{mg} \mathrm{L}^{-1}$. This phosphorus concentration was selected according to Welander et al. [16]. The shift to a higher phosphorus load, keeping $C / N=2$, had a significant effect on nitrogen-nitrate removal efficiency, which became close to $100 \%$. In fact, higher phosphorus concentration stimulates cell production in detriment of extracellular polymers production in the biofilm, consequently increasing biofilm activity. This is corroborated by other authors who reported that a deficiency of some nutrients in the medium could enhance polysaccharide production instead of cell production [17].

After approximately 10 days of operation, the $\mathrm{C} / \mathrm{N}$ ratio of the culture was modified from 2 to 1.4 (equal to the theoretical value) to adjust the operational conditions to the stoichiometric ones for the nitrate and acetate removal reaction also considering microbial growth. No effect on the nitrate consumption was observed when the $\mathrm{C} / \mathrm{N}$ ratio decreased, as the removal efficiency remained constant and close to $100 \%$. Taking into account the high performance of the anoxic RBC in terms of nitrate removal, on day 14 the nitrate load was doubled but the nitrate reduction remained constant. Finally, in order to decrease effluent COD concentration, ozonated leachate was fed to the reactor. The nitrate removal slightly decreased, which can be attributed to the biofilm acclimatisation to a different type of influent. It was a transitory period since nitrate removal efficiency recovered quickly and was kept around $99 \%$ after day 20 , indicating that the denitrifying biofilm did not lose its per- 
formance. It is worth mentioning that the ozonation of the landfill leachate caused some oxidation of ammonium to nitrate leading to an increase on the fed nitrate load. Excluding the periods with insufficient phosphorus concentration, effluent $\mathrm{N}-\mathrm{NO}_{3}{ }^{-}$concentrations were less than $10 \mathrm{mg} \mathrm{L}^{-1}$, being below the established limit for discharge into fresh water $\left(10-30 \mathrm{mg} \mathrm{N}-\mathrm{NO}_{3}{ }^{-} \mathrm{L}^{-1}\right)$ [18]. The

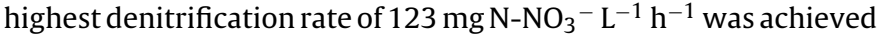
under a $\mathrm{C} / \mathrm{N}$ ratio of $1.4,10 \mathrm{mg} \mathrm{P}_{-} \mathrm{PO}_{4}{ }^{3-} \mathrm{L}^{-1}$ and approximately $1240 \mathrm{mg} \mathrm{N}-\mathrm{NO}_{3}{ }^{-} \mathrm{L}^{-1}$ (ozonated leachate). Calli et al. [19] obtained denitrification rates in the range of 33.3-120.8 $\mathrm{mg} \mathrm{N}^{-\mathrm{NO}_{x}}{ }^{-} \mathrm{L}^{-1} \mathrm{~h}^{-1}$ $\left(\mathrm{N}-\mathrm{NO}_{x}\right.$-nitrogen from nitrate and nitrite compounds) in the treatment of a young landfill leachate with sodium acetate as carbon source. A denitrification rate of $55 \mathrm{mg} \mathrm{N}-\mathrm{NO}_{3}{ }^{-} \mathrm{L}^{-1} \mathrm{~h}^{-1}$ was achieved by Welander et al. [16] in a suspended carrier biofilm reactor, which treated leachate, but using methanol as external carbon source. So, the denitrification rate found in the present study indicates a very good performance of the anoxic RBC.

From Fig. 2(b) it can be seen that, in the beginning of the anoxic experiment, a significant part of nitrate was converted to nitrite, which accumulated in the effluent. Nitrite accumulation during denitrification of landfill leachates has been observed in many studies $[20,21]$. However, it is very important to avoid N$\mathrm{NO}_{2}{ }^{-}$accumulation because it can lead to inhibition of the bacterial growth and the denitrification process [20]. Moreover, nitrite is

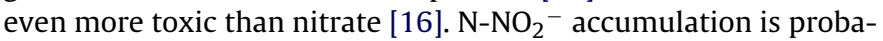
bly related with the activity of the nitrite reductase enzyme, which can be inhibited by nitrate or to low oxygen concentrations [20,22]. When influent phosphorus concentration was changed to $10 \mathrm{mg}$ P$\mathrm{PO}_{4}{ }^{3-} \mathrm{L}^{-1}$, all nitrate was reduced to gaseous nitrogen and no nitrite was measured in the effluent. Further changes in the experimental conditions, namely $\mathrm{C} / \mathrm{N}$ ratio, nitrate load and influent type did not cause nitrite production.

Ammonium is one of the worst polluting agents for aquatic ecosystems and may restrain the microorganisms' activity. Ammonium concentrations in the effluent remained relatively unchanged until approximately 6 days of reactor operation. $\mathrm{N}_{-} \mathrm{NH}_{4}{ }^{+}$removal observed onwards was probably due to a higher assimilation of ammonium for biomass growth triggered by the increase in phosphorus concentration. Another explanation might be due to ammonium reduction by nitrite to form gaseous nitrogen. In fact, in the beginning there was some nitrite accumulation and a low ammonium reduction but when the ammonium reduction raised, nitrite accumulation was almost negligible.

No significant effect of $\mathrm{C} / \mathrm{N}$ ratio, nitrate load or effluent type on ammonium removal was noticed. As previously mentioned, the ozonation of the landfill leachate caused a decrease on initial ammonium load.

The produced gas flow rate varied according to the profile of nitrogen-nitrate removal efficiency (Fig. 3). Molecular nitrogen $\left(\mathrm{N}_{2}\right)$ was the most abundant compound detected in gas composition (around 92\%). Production of $\mathrm{N}_{2} \mathrm{O}$ remained around $0.2 \%$ (minimum detection value) except when the influent was changed to ozonated leachate, which can be due to the biofilm acclimatisation, as mentioned before. Dissolved oxygen concentration in the reactor was detected only in the beginning of the experiment, remaining below the limit of detection until the end. Initially, biological denitrification was considered to be strictly anoxic [23], however, with a certain number of bacteria, denitrification occurs even in the presence of $\mathrm{O}_{2}$ [24]. No methane or hydrogen sulfide gases were detected by the measuring system.

\subsubsection{Carbonaceous compounds}

TOC and carbon-acetate concentration time profile as well as removal efficiencies are shown in Fig. 4. During the two first periods of operation the reactor presented an average value of $19.2 \%$ and $33.3 \%$ for TOC and carbon-acetate removal efficiency, respec-

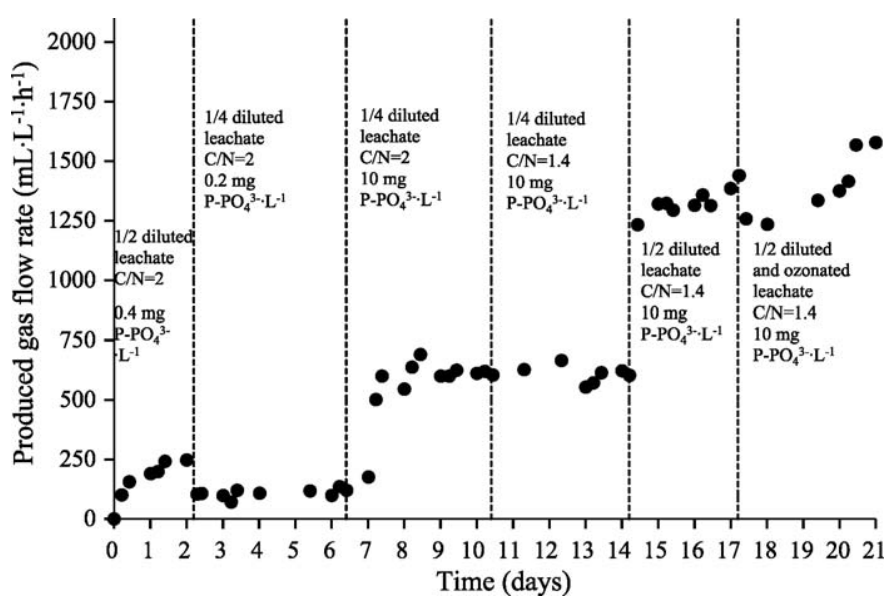

Fig. 3. Produced gas flow rate in the denitrifying reactor throughout time.

tively. These low values are due to poor denitrification efficiency. From day 6 onwards, when phosphorus influent concentration was changed to $10 \mathrm{mg} \mathrm{P}_{-} \mathrm{PO}_{4}{ }^{3-} \mathrm{L}^{-1}$, keeping $\mathrm{C} / \mathrm{N}=2$, a better reactor performance in terms of nitrate removal was obtained also yielding an increase in carbon consumption, reflecting on effluent TOC and acetate concentrations. In spite of a higher carbon removal, acetate still remained in the effluent flow, which implies that the reactor was receiving enough carbon to facilitate the denitrifi-
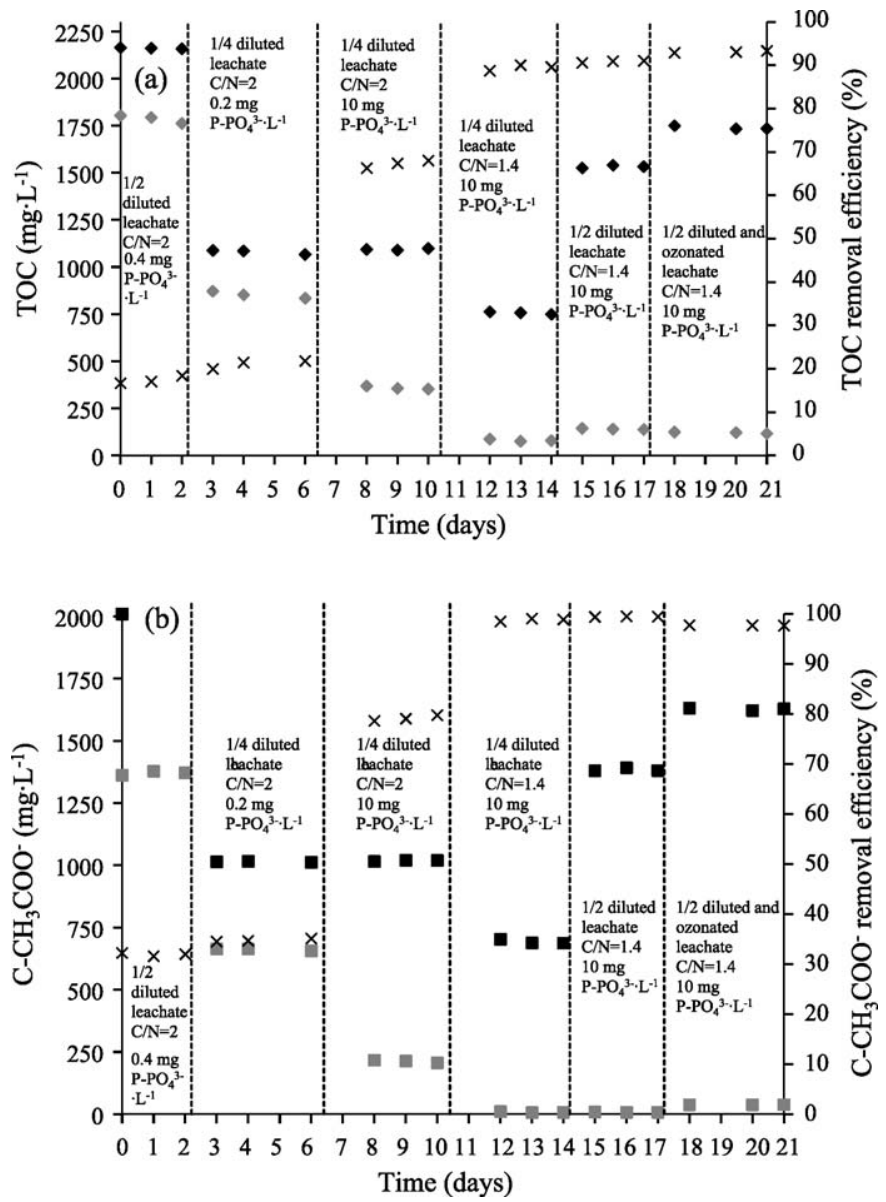

Fig.4. Carbonaceous compounds profile in the denitrifying reactor throughout time. (a) Influent $(\diamond)$ and effluent $(\diamond)$ TOC concentration and TOC removal efficiency $(x)$. (b) Influent ( $)$ and effluent $(\square) \mathrm{C}_{-} \mathrm{CH}_{3} \mathrm{COO}^{-}$concentration and $\mathrm{C}-\mathrm{CH}_{3} \mathrm{COO}^{-}$removal efficiency $(x)$. 
cation process. Under a $\mathrm{C} / \mathrm{N}$ ratio of 1.4 , acetate was completely consumed but TOC was still detected in the effluent. The effluent TOC values corresponded entirely to the contribution of the landfill leachate composition. These results reveal, as expected, that the organic matter present in the leachate was non-biodegradable and the denitrifying biofilm could not use it, preferring the easily biodegradable carbon. Another important conclusion is that, since only carbon from acetate was being used, the reactor operated, in practice, under a $\mathrm{C} / \mathrm{N}$ ratio below 1.4 , and this experimental $\mathrm{C} / \mathrm{N}$ value (around 1.3) was enough to achieve a nitrate removal of approximately $100 \%$.

In order to increase leachate biodegradability and to reduce the organic content in the biological treated effluent, the two-fold diluted leachate was previously treated by ozonation at $\mathrm{pH} 9$ and with an ozone dose of $0.112 \mathrm{~g} \mathrm{O}_{3} \mathrm{~L}^{-1}$. This pre-treatment led to a TOC removal of $28 \%$. Denitrifying biofilm activity was not affected when the reactor started to be fed with ozonated leachate. The biological treatment of the ozonated effluent resulted in a slight decrease in acetate removal efficiency from about $100 \%$ to $98 \%$. There was also a reduction in the total carbon content in the biological treated effluent. These results might indicate that, after ozonation, a small organic fraction of the landfill leachate was transformed into more readily biodegradable compounds, able to be consumed by the biofilm. However, this effluent still contained an organic fraction recalcitrant to biological degradation. The values of soluble COD measured at the inlet and outlet of the reactor indicate that, although not very significantly, ozonation allowed reducing the effluent $C O D$ concentration to a value close to the discharge standard value.

\subsection{3. $\mathrm{pH}$}

Throughout the experiment, $\mathrm{pH}$ values increased from 6.8-7.1 in the influent to 8.0-9.5 in the effluent. The observed $\mathrm{pH}$ trend might be attributed to the conversion of $\mathrm{N}^{-\mathrm{NO}_{3}}{ }^{-}$to gaseous nitrogen in the reactor, which consumed hydrogen ion. It is important to note that after ozonation at $\mathrm{pH} 9$, the $\mathrm{pH}$ of the landfill leachate dropped around 2 units bringing the ozonated leachate $\mathrm{pH}$ to neutral. Therefore, no further $\mathrm{pH}$ adjustment was necessary before the biological treatment.

\subsection{Biofilm denitrifying activity}

A key parameter in water and wastewater treatment technology is microbial activity, expressed in terms of substrate removal ability. In order to determine the denitrifying biofilm activity, batch tests were performed using the biofilm removed from the continuous denitrifying reactor. The abiotic tests showed that no nitrate or carbon was removed, indicating that the denitrification process was completely due to biological activity. From Fig. 5(a) and (b) it can be seen that, under anoxic heterotrophic conditions, nitrate was completely consumed in $12 \mathrm{~h}$ and $14 \mathrm{~h}$ for ozonated and nonozonated landfill leachate, respectively. Some nitrite accumulated, but it was completely consumed until the end of the experiment. $\mathrm{N}_{2}$ was the main gas produced. The profiles of nitrogenous compounds allow to conclude that denitrification was faster with the ozonated leachate. Considering carbon consumption, when
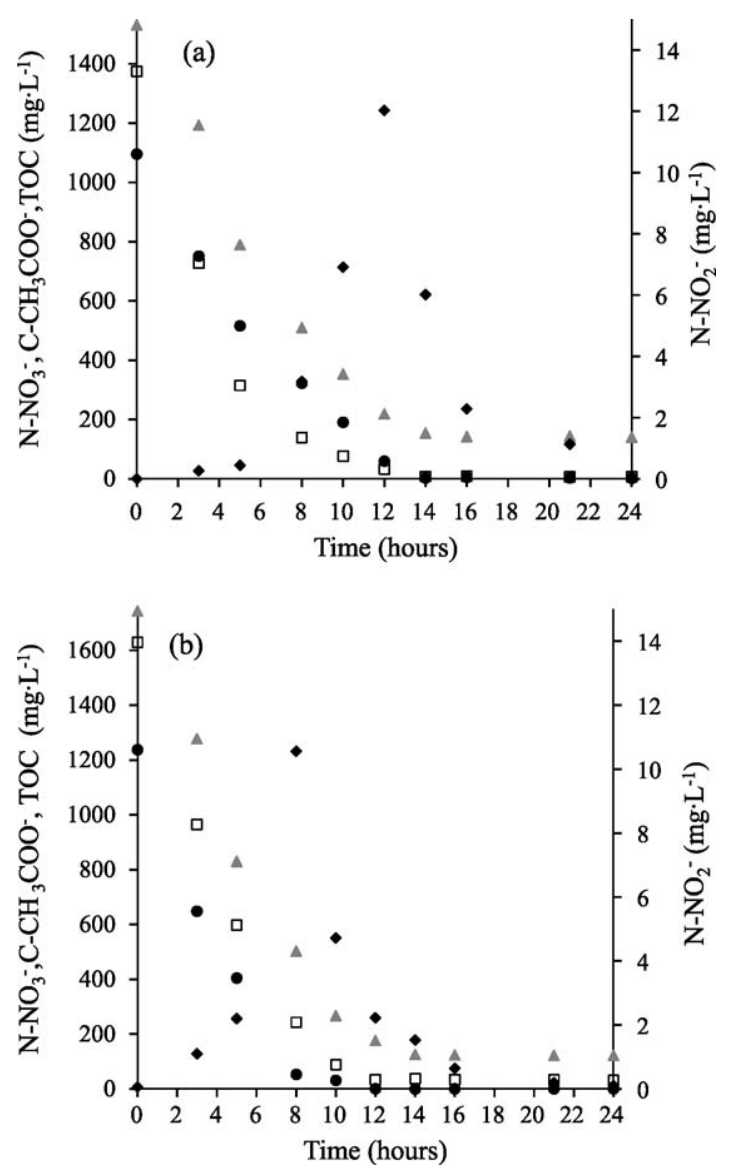

Fig. 5. Nitrogen-nitrate $(\bullet)$, nitrogen-nitrite $(\bullet)$, carbon-acetate $(\square)$ and total organic carbon ( $\boldsymbol{\Delta}$ ) profiles during biofilm denitrifying activity tests of a nonozonated (a) and ozonated (b) two-fold diluted landfill leachate.

ozonated leachate was used some acetate remained in the effluent, while in the non-ozonated leachate acetate was completely consumed. Denitrification of leachate without additional acetate showed that the nitrate reduction was negligible. However, some nitrate and carbon consumption were noticed in the medium with ozonated leachate. These results confirm that ozonation converted some high molecular weight compounds, which were difficult to degrade into easily biodegradable compounds.

Ammonium was determined in the beginning and at the end of the batch tests and, similarly to the continuous experiment, ammonium removal was verified.

The activity of the biofilm was measured as specific consumption rate for nitrate and acetate. The specific denitrification rate (expressed in $\mathrm{g}$ of $\mathrm{N}-\mathrm{NO}_{3}{ }^{-}$removed per $\mathrm{g}$ of vial VSS per day) and the specific carbon-acetate consumption rate (expressed in $\mathrm{g}$ of $\mathrm{C}$ $\mathrm{CH}_{3} \mathrm{COO}^{-}$consumed per $\mathrm{g}$ of vial VSS per day) are shown in Table 3 . The specific rates were calculated for the total duration of each run, in order to obtain an overall assessment of the ability of the biofilm to perform under the conditions investigated. The initial nitrate concentration was around 1240 and $1090 \mathrm{mg} \mathrm{N}-\mathrm{NO}_{3}{ }^{-} \mathrm{L}^{-1}$ for the

Table 3

Specific denitrification and acetate consumption rates in biofilm denitrifying activity tests.

\begin{tabular}{|c|c|c|c|c|}
\hline & \multicolumn{2}{|c|}{ Non-ozonated leachate } & \multicolumn{2}{|l|}{ Ozonated leachate } \\
\hline & Without acetate & With acetate & Without acetate & With acetate \\
\hline $\begin{array}{l}\text { Specific denitrification rate ( } \mathrm{g} \\
\mathrm{N}-\mathrm{NO}_{3}{ }^{-} \mathrm{g}^{-1} \mathrm{VSS}_{\text {day }}{ }^{-1} \text { ) }\end{array}$ & $0.0008 \pm 0.0002$ & $0.830 \pm 0.007$ & $0.0016 \pm 0.0001$ & $0.864 \pm 0.007$ \\
\hline $\begin{array}{l}\text { Specific carbon-acetate consumption } \\
\text { rate }\left(\mathrm{g} \mathrm{C}_{-} \mathrm{CH}_{3} \mathrm{COO}^{-} \mathrm{g}^{-1} \mathrm{VSS}^{-1 a y}{ }^{-1}\right)\end{array}$ & - & $1.043 \pm 0.002$ & - & $1.112 \pm 0.004$ \\
\hline
\end{tabular}


ozonated and non-ozonated leachate, respectively. When acetate was added, the $\mathrm{C} / \mathrm{N}$ ratio was 1.4 .

In a previous study, Reyes-Avila et al. [25] reported a specific denitrification rate of $1.9 \mathrm{~g} \mathrm{~N}-\mathrm{NO}_{3}{ }^{-} \mathrm{g}^{-1} \mathrm{VSS} \mathrm{Vay}^{-1}$ and a specific carbon-acetate consumption rate of $1.9 \mathrm{~g} \mathrm{C}_{-} \mathrm{CH}_{3} \mathrm{COO}^{-} \mathrm{g}^{-1}$ VSS day $^{-1}$ in batch tests using acetate, $\mathrm{C} / \mathrm{N}=1.4$ and $73 \mathrm{mg} \mathrm{N}-$ $\mathrm{NO}_{3}{ }^{-} \mathrm{L}^{-1}$, but treating a synthetic refinery wastewater. The lower values of substrate consumption rates found in this study might be justified by the complexity of the leachate and the much higher nitrate concentration.

\section{Conclusions}

The results demonstrate that the anoxic rotating biological contactor is very effective having a great potential in the denitrification of a mature landfill leachate with high nitrate load, using acetate as additional carbon source. The supplementary addition of phosphorus played a determinant role on nitrate removal.

The pre-ozonation of the already treated leachate before RBC denitrification led to a moderate TOC reduction, which indicates the high complexity and refractory nature of this leachate.

Future research should focus on improving the pre-treatment of the leachate before the biological process. Considering the ammonium content of the treated leachate, a system involving nitrification should also be evaluated.

\section{Acknowledgement}

The authors are grateful for the financial support provided from Fundação para a Ciência e Tecnologia (FCT) through the grants SFRH/BD/24715/2005 and SFRH/BPD/26803/2006.

\section{References}

[1] Wang Q, Feng C, Zhao Y, Hao C. Denitrification of nitrate contaminated groundwater with a fiber-based biofilm reactor. Bioresour Technol 2009;100: 2223-7.

[2] Teixeira P, Oliveira R. Denitrification by Alcaligenes denitrificans in a closed rotating biological contactor. Biotechnol Lett 2000;22:1789-92.

[3] Alves C, Melo L, Vieira M. Influence of medium composition on the characteristics of a denitrifying biofilm formed by Alcaligenes denitrificans in a fluidised bed reactor. Process Biochem 2002;37:837-45.

[4] Cortez S, Teixeira P, Oliveira R, Mota M. Effect of operating parameters on denitrification in an anoxic rotating biological contactor. Environ Technol 2009;30:1381-9.
[5] Mohseni-Bandpi A, Elliott D, Momeny-Mazdeh A. Denitrification of groundwater using acetic acid as a carbon source. Water Sci Technol 1999;40:53-9.

[6] Cema G, Wiszniowski J, Zabczynski S, Zablocka-Godlewska E, Raszka A Surmacz-Gorska J. Biological nitrogen removal from landfill leachate by deammonification assisted by heterotrophic denitrification in a rotating biological contactor (RBC). Water Sci Technol 2007;55:35-42.

[7] Spengel D, Dzombak D. Treatment of a landfill leachate with rotating biological contactors: bench-scale experiments. Res J Water Pollut Control Fed 1991;63:971-81.

[8] Castillo E, Vergara M, Moreno Y. Landfill leachate treatment using a rotating biological contactor and an upward-flow anaerobic sludge bed reactor. Waste Manage 2007;27:720-6.

[9] Wang F, Smith DW, El-Din MG. Application of advanced oxidation methods for landfill leachate treatment-a review. J Environ Eng Sci 2003;2:413-27.

[10] Haapea P, Korhonen S, Tuhkanen T. Treatment of industrial landfill leachates by chemical and biological methods: ozonation, ozonation hydrogen peroxide, hydrogen peroxide and biological post-treatment for ozonated water. Ozone Sci Eng 2002;24:369-78.

[11] Geenens D, Bixio B, Thoeye C. Combined ozone-activated sludge treatment of landfill leachate. Water Sci Technol 2001;44:359-65.

[12] Tam N, Wong Y, Leung G. Effect of exogenous carbon sources on removal of inorganic nutrient by the nitrification-denitrification process. Water Res 1992;26:1229-36.

[13] Elefsiniotis P, Wareham D. Utilization patterns of volatile fatty acids in the denitrification reaction. Enzyme Microb Technol 2007;41:92-7.

[14] APHA, AWWA, WPCF. Standard methods for the examination of water and wastewater. 17th ed. Washington, DC: American Public Health Association (APHA)/American Water Works Association (AWWA)/Water Pollution Control Federation (WPCF); 1989.

[15] McCarty P, Beck L, Amant P. Biological denitrification of wastewaters by addition of organic materials. In: Proceedings of the 24th Purdue Industrial Waste Conference. Indiana: Purdue University; 1969. p. 1271-85.

[16] Welander U, Henrysson T, Welander T. Biological nitrogen removal from municipal landfill leachate in a pilot scale suspended carrier biofilm process. Water Res 1998;32:1564-70.

[17] Veiga MC, Mendez R, Lema JM. Development and stability of biofilms in bioreactors. In: Melo LF, Bott TR, Fletcher M, Capdeville B, editors. Biofilms - Science and Technology. Netherlands: Kluwer Academic Publishers; 1992. p. 421-34.

[18] Council Directive 91/271/EE.C. Council Directive 91/271/EEC of 21 May 1991 on urban waste water treatment. Off J Eur Comm 1991;L/135:40-52.

[19] Calli B, Mertoglu B, Inanc B. Landfill leachate management in Istanbul: applications and alternatives. Chemosphere 2005;59:819-29.

[20] Martienssen M, Schops R. Biological treatment of leachate from solid waste landfill sites-alterations in the bacterial community during the denitrification process. Water Res 1997;31:1164-70.

[21] Sun H, Yang Q, Peng Y, Shi X, Wang S, Zhang S. Nitrite accumulation during the denitrification process in SBR for the treatment of pre-treated landfill leachate. Chin J Chem Eng 2009;17:1027-31.

[22] van Rijn J, Tal Y, Schreier HJ. Denitrification in recirculating systems: theory and applications. Aquacult Eng 2006;34:364-76.

[23] Payne W. Reduction of nitrogenous oxides by microorganisms. Bacteriol Rev 1973;37:409-52.

[24] Lukow T, Diekmann H. Aerobic denitrification by a newly isolated heterotrophic bacterium strain TL1. Biotechnol Lett 1997;19:1157-9.

[25] Reyes-Avila J, Razo-Flores E, Gomez J. Simultaneous biological removal of nitrogen, carbon and sulfur by denitrification. Water Res 2004;38:3313-21. 